\title{
Effect of Calcium Sources and Particle Size on Performance and Eggshell Quality in Laying Hens
}

\author{
Arzu Erol Tunç ${ }^{1}$, Yusuf Cufadar ${ }^{2 *}$ \\ ${ }^{1}$ Lalahan Livestock Central Research Institute, Ankara, Turkey \\ ${ }^{2}$ Department of Animal Science, Agriculture Faculty, Selçuk University, 42075 Konya, Turkey
}

A R T I C LE IN F O

\section{Article history:}

Received 31 October 2014

Accepted 18 December 2014

Available online, ISSN: 2148-127X

\section{Keywords:}

Egg shell

Egg quality

Layer hens

Limestone

Oyster shell

Performance

${ }^{*}$ Corresponding Author:

E-mail: ycufadar@selcuk.edu.tr
A B S T R A C T

An experiment was conducted to determine the effect of different combination calcium sources and particle size on performance and egg shell quality in layer hens. In the experiment, 198 brown laying hens at 44 week of age were randomly assigned into 11 treatments groups. The experimental diets consisted of different calcium sources (Fine limestone, large limestone, large oyster shell and large egg shell) and their different combination. The experimental unit consisted of a groups of three hens, thus each treatment was replicated six times. Different calcium sources and particle size addition to the laying hens diet had no significantly effect on body weight gain, egg production, egg mass, feed intake, feed conversion ratio, egg specific gravity, egg shell weight, egg shell thickness and egg shell breaking strength but egg weight had significantly affected by the treatments. The significantly highest egg weight was found in laying hens fed with $50 \%$ fine limestone and $50 \%$ large limestone. Dietary different Ca sources had a significant effect on $\mathrm{Ca}, \mathrm{P}$ and $\mathrm{Mg}$ as mineral contents of eggshell and tibia. In the present study, when dietary large calcium sources (limestone, oyster shell and egg shell) had no effect on performance and eggshell quality parameters in laying hens. However, dietary containing at least $50 \%$ large calcium sources had positive effect on mineral contents of tibia.

\section{Introduction}

Calcium $(\mathrm{Ca})$ is one of the essential minerals in poultry nutrition. In addition to its vital functions as the main component of bone structure and participation in acid-base balance and enzymatic system, calcium is the also the main component of the eggshell. It is estimated that each egg contains $2.2 \mathrm{~g}$ of calcium, present mainly in the eggshell (Pelicia et al., 2009). Egg producers primarily use 2 supplemental sources of dietary $\mathrm{Ca}$, oyster shell or limestone. Oyster shell and limestone both provide $\mathrm{Ca}$ in the form of $\mathrm{Ca}$ carbonate, and each contains about $38 \% \mathrm{Ca}$. In addition, egg shell could be an alternative source of calcium for laying hens. The $\mathrm{Ca}$ level of egg shell has comparable to limestone and oyster shell (Sheideler, 1998). However, limestone costs considerably less than oyster shell (Saunders-Blades et al., 2009).

The particle size of $\mathrm{Ca}$ sources may influence its availability to the laying hens. As eggshell is usually formed during the night, when hens do not eat feed, the advantage of the use of larger particles is its slower passage through the gastrointestinal tract. This makes $\mathrm{Ca}$ available for eggshell formation, with consequent lower mobilization of bone $\mathrm{Ca}$ by the laying hens (Harms, 1982). Scott et al. (1971) speculated that the larger particles remain in the upper digestive tract (crop and gizzard) for a longer period of time than the ground $\mathrm{Ca}$ sources, resulting in $\mathrm{Ca}$ being available to the hen for a longer period of time. A large particle $\mathrm{Ca}$ may therefore be beneficial to the hen during the 8 to $9 \mathrm{~h}$ dark period when feed is not consumed, but $\mathrm{Ca}$ requirements are high due to eggshell formation (Etches, 1987). Rao et al. (1992) reported that minimum particle size less than 1.0 $\mathrm{mm}$, did not sustain retention in the gizzard. Scheideler (1998) reported significantly greater specific gravity of the eggs from the hens on the diets, which included large particle size $\mathrm{Ca}$ (fine and large limestone $50: 50$ or $75: 25$ limestone: oyster shell in the diets) compared with hens fed with diets containing $100 \%$ fine limestone or $100 \%$ ground eggshell. Scheideler (2004) recommended that laying hens fed with at least $25 \%$ of their calcium from a large particle calcium source. Also, Ahmad and Balander (2003) reported higher egg specific gravity with the partial replacement of limestone $(50 \%)$ with oyster shell as the calcium source. Lichovnikova (2007) recommended that two-thirds of the calcium source should be fed in the form of large particles (limestone grit or oyster shell) in the last third of the laying period to ensure good eggshell quality. Scott et al. (1982) reported that shell quality was improved when part of the fine limestone in the diet was substituted by large particle limestone or oyster shell. Safaa et al. (2008) reported that brown laying hens in the late phase of production period 
require more than $3.5 \% \mathrm{Ca}$ in the diet and that the substitution of $40 \%$ of fine limestone with large limestone and oyster shell did not affect performance and has little impact on shell quality. Koreleski and Swiatkiewicz (2004) reported that egg shell thickness was increased fed with diet containing large limestone (60-80\%) in laying hens. Pavlovski et al. (2003) stated that replacing 60-80\% of fine limestone by larger particle size limestone had positive effects on eggshell quality. Skrivan et al. (2010) reported that large limestone $(>1.0 \mathrm{~mm})$ should be considered rather than fine limestone $(<1.0 \mathrm{~mm})$ when formulating diets for laying hens both in the early and the late phase of production periods. Recommendations regarding the ideal limestone particle size for laying hens were under continued investigation and ranged generally between 1.40 and $5.60 \mathrm{~mm}$, depending on the production status and age of the hens (De Witt et al., 2009).

The objective of this study was to determining the effects of different calcium sources and particle size on the performance, egg quality and egg shell and tibia mineral content in laying hens.

\section{Material and Methods}

A total of 198 H\&N Brown Nick hens, 44 week of age were randomly assigned into 11 treatments groups. Experimental diets contained fine particle limestone $(<2$ $\mathrm{mm})$, large particle $(2-5 \mathrm{~mm})$ limestone, oyster shell and egg shell and their different combinations. Experimental diets are as follows; $100 \%$ fine limestone (diet 1), 50\% fine limestone and 50\% large limestone (diet 2), 50\% fine limestone and 50\% oyster shell (diet 3), 50\% fine limestone and 50\% egg shell (diet 4), 50\% fine limestone, $25 \%$ large limestone and $25 \%$ oyster shell (diet 5), 50\% fine limestone, $25 \%$ large limestone and $25 \%$ egg shell (diet 6), $50 \%$ fine limestone, $25 \%$ oyster shell and $25 \%$ egg shell (diet 7), $75 \%$ fine limestone and $25 \%$ large limestone (diet 8), $75 \%$ fine limestone and $25 \%$ oyster shell (diet 9), $75 \%$ fine limestone and $25 \%$ egg shell (diet 10) and $25 \%$ fine limestone, $25 \%$ large limestone, $25 \%$ oyster shell and $25 \%$ egg shell (diet 11).

The 11 different experimental diets were tested with six replicates per treatments and three hens per experimental unit. Hens were housed in a layer house equipped with 66 metal battery cages $(50 \times 50 \times 40 \mathrm{~cm})$. Experimental diets were offered to the nutrient requirements for brown laying hens (NRC, 1994) and formulated to be isocaloric and isonitrogenous with only the $\mathrm{Ca}$ particle sizes and sources in the diets changing (Table 1). Hens were offered feed and water ad libitum throughout the experiment (44-56 week of age). Lighting was provided for $16 \mathrm{~h} /$ day from $05: 00$ to $21: 00 \mathrm{~h}$ throughout the experimental period. Housed in layer cages were environmentally controlled room $\left(23-25^{\circ} \mathrm{C}\right)$.

Body weight gain (BWG) was calculated by the initial and final body weight of hens. Feed intake (FI) and Egg weight (EW) were recorded biweekly. Egg production (EP) was recorded daily and Egg mass (EM) was calculated from collecting data of EP and EW at biweekly via: $E M=(E P \times E W)$. Feed conversion ratio (FCR; $g$ of feed $\mathrm{g}$ of egg) was calculated via: $\mathrm{FCR}=\mathrm{FI}$ ( $\mathrm{g}$ of feed/hen) / EM (g of egg/hen).

Table 1 Composition of experimental diets

\begin{tabular}{|c|c|c|c|c|c|c|c|c|c|c|c|}
\hline \multicolumn{12}{|c|}{ Experimental diets } \\
\hline Ingredients (\%) & 1 & 2 & 3 & 4 & 5 & 6 & 7 & 8 & 9 & 10 & 11 \\
\hline Corn & 56.00 & 56.00 & 56.00 & 56.00 & 56.00 & 56.00 & 56.00 & 56.00 & 56.00 & 56.00 & 56.00 \\
\hline Barley & 7.00 & 7.00 & 7.00 & 7.00 & 7.00 & 7.00 & 7.00 & 7.00 & 7.00 & 7.00 & 7.00 \\
\hline Soybean meal & 17.00 & 17.00 & 17.00 & 17.00 & 17.00 & 17.00 & 17.00 & 17.00 & 17.00 & 17.00 & 17.00 \\
\hline Sunflower meal & 7.00 & 7.00 & 7.00 & 7.00 & 7.00 & 7.00 & 7.00 & 7.00 & 7.00 & 7.00 & 7.00 \\
\hline Vegetable oil & 1.63 & 1.63 & 1.63 & 1.63 & 1.63 & 1.63 & 1.63 & 1.63 & 1.63 & 1.63 & 1.63 \\
\hline Limestone $^{1}$ & 9.50 & 4.75 & 4.75 & 4.75 & 4.75 & 4.75 & 4.75 & 7.13 & 7.13 & 7.13 & 2.38 \\
\hline Di-Ca-phosphate & 1.15 & 1.15 & 1.15 & 1.15 & 1.15 & 1.15 & 1.15 & 1.15 & 1.15 & 1.15 & 1.15 \\
\hline Salt & 0.35 & 0.35 & 0.35 & 0.35 & 0.35 & 0.35 & 0.35 & 0.35 & 0.35 & 0.35 & 0.35 \\
\hline Vitamin Premix ${ }^{2}$ & 0.25 & 0.25 & 0.25 & 0.25 & 0.25 & 0.25 & 0.25 & 0.25 & 0.25 & 0.25 & 0.25 \\
\hline Methionine & 0.11 & 0.11 & 0.11 & 0.11 & 0.11 & 0.11 & 0.11 & 0.11 & 0.11 & 0.11 & 0.11 \\
\hline Limestone $^{3}$ & --- & 4.75 & --- & --- & 2.38 & 2.38 & --- & 2.38 & --- & --- & 2.38 \\
\hline Oyster shell ${ }^{3}$ & --- & --- & 4.75 & --- & 2.38 & --- & 2.38 & --- & 2.38 & --- & 2.38 \\
\hline Egg shell ${ }^{3}$ & --- & --- & --- & 4.75 & --- & 2.38 & 2.38 & --- & --- & 2.38 & 2.38 \\
\hline Total & 100.0 & 100.0 & 100.0 & 100.0 & 100.0 & 100.0 & 100.0 & 100.0 & 100.0 & 100.0 & 100.0 \\
\hline \multicolumn{12}{|c|}{ Calculated nutrients } \\
\hline M. Energy ${ }^{4}$ & 2729 & 2729 & 2729 & 2729 & 2729 & 2729 & 2729 & 2729 & 2729 & 2729 & 2729 \\
\hline C. $\operatorname{protein}^{5}(\%)$ & 15.22 & 15.22 & 15.22 & 15.22 & 15.22 & 15.22 & 15.22 & 15.22 & 15.22 & 15.22 & 15.22 \\
\hline Calcium (\%) & 3.56 & 3.56 & 3.56 & 3.56 & 3.56 & 3.56 & 3.56 & 3.56 & 3.56 & 3.56 & 3.56 \\
\hline Available $\mathrm{P}^{6}(\%)$ & 0.335 & 0.335 & 0.335 & 0.335 & 0.335 & 0.335 & 0.335 & 0.335 & 0.335 & 0.335 & 0.335 \\
\hline Lysine $(\%)$ & 0.72 & 0.72 & 0.72 & 0.72 & 0.72 & 0.72 & 0.72 & 0.72 & 0.72 & 0.72 & 0.72 \\
\hline Methionine (\%) & 0.33 & 0.33 & 0.33 & 0.33 & 0.33 & 0.33 & 0.33 & 0.33 & 0.33 & 0.33 & 0.33 \\
\hline
\end{tabular}

${ }^{1}$ Fine particle sizes $(<2 \mathrm{~mm})$ form a Ca source. ${ }^{2}$ Premix provided the following per kg of diet: retinyl acetate, $4.0 \mathrm{mg}$; cholecalciferol, $0.055 \mathrm{mg}$; DL$\alpha$-tocopheryl acetate, $11 \mathrm{mg}$; nicotinic acid, $44 \mathrm{mg}$; calcium-D-pantothenate, $8.8 \mathrm{mg}$; riboflavine sodium phosphate $5.8 \mathrm{mg}$; thiamine hidrocloride 2.8 $\mathrm{mg}$; cyanocobalamin, $0.66 \mathrm{mg}$; folic acid, $1 \mathrm{mg}$; biotin, $0.11 \mathrm{mg}$; coline, $220 \mathrm{mg}$; Mn, $60 \mathrm{mg}$; Fe, $30 \mathrm{mg} ; \mathrm{Zn}, 50 \mathrm{mg} ; \mathrm{Cu}, 5 \mathrm{mg}$; I, $1.1 \mathrm{mg}$; Se, $0.1 \mathrm{mg}$. ${ }^{3}$ Large particle sizes $(2-5 \mathrm{~mm})$ form a Ca sources. ${ }^{4}$ Metabolizable Energy (Kcal/kg). ${ }^{5}$ Crude protein $(\%) .,{ }^{6}$ Available phosphorus $(\%)$. 
Table 2 Effect of different calcium sources and particle size on laying performance from 44 to 56 weeks of age*

\begin{tabular}{c|cccccc}
\hline Diets & BWG $^{1}$ & ${ }^{2} \mathrm{EP}$ & ${ }^{3} \mathrm{EW}$ & ${ }^{4} \mathrm{EM}$ & ${ }^{5} \mathrm{FI}$ & ${ }^{6} \mathrm{FCR}$ \\
\hline 1 & $-32.39 \pm 23.7$ & $89.2 \pm 2.78$ & $62.03 \pm 0.78^{\mathrm{ab}}$ & $55.48 \pm 2.11$ & $108.16 \pm 2.41$ & $1.96 \pm 0.06$ \\
2 & $12.63 \pm 40.6$ & $89.1 \pm 2.48$ & $63.24 \pm 0.66^{\mathrm{a}}$ & $56.41 \pm 1.79$ & $105.74 \pm 1.63$ & $1.89 \pm 0.04$ \\
3 & $-77.28 \pm 51.5$ & $91.0 \pm 1.85$ & $59.31 \pm 0.78^{\mathrm{c}}$ & $54.08 \pm 1.69$ & $107.45 \pm 2.08$ & $1.99 \pm 0.03$ \\
4 & $-23.83 \pm 15.8$ & $91.9 \pm 1.26$ & $62.27 \pm 0.89^{\mathrm{ab}}$ & $57.21 \pm 0.89$ & $108.16 \pm 2.58$ & $1.89 \pm 0.04$ \\
5 & $4.17 \pm 10.8$ & $92.6 \pm 1.15$ & $60.18 \pm 0.93^{\mathrm{bc}}$ & $55.81 \pm 1.30$ & $106.68 \pm 2.91$ & $1.92 \pm 0.03$ \\
6 & $-42.50 \pm 15.1$ & $91.1 \pm 1.94$ & $61.31 \pm 0.52^{\mathrm{abc}}$ & $55.90 \pm 1.29$ & $106.25 \pm 2.35$ & $1.91 \pm 0.05$ \\
7 & $-20.84 \pm 9.6$ & $93.7 \pm 0.93$ & $61.28 \pm 0.66^{\mathrm{abc}}$ & $57.48 \pm 0.92$ & $107.72 \pm 2.33$ & $1.88 \pm 0.03$ \\
8 & $-37.56 \pm 35.9$ & $92.8 \pm 0.95$ & $61.90 \pm 0.94^{\mathrm{ab}}$ & $57.51 \pm 1.39$ & $106.08 \pm 1.92$ & $1.85 \pm 0.04$ \\
9 & $-3.45 \pm 32.5$ & $90.2 \pm 2.96$ & $59.98 \pm 0.68^{\mathrm{bc}}$ & $54.18 \pm 1.92$ & $109.05 \pm 1.62$ & $2.03 \pm 0.07$ \\
10 & $-8.33 \pm 37.0$ & $94.1 \pm 2.42$ & $61.81 \pm 0.79^{\mathrm{ab}}$ & $58.16 \pm 1.39$ & $108.09 \pm 2.63$ & $1.86 \pm 0.03$ \\
11 & $52.00 \pm 11.7$ & $92.7 \pm 1.55$ & $62.54 \pm 0.75^{\mathrm{ab}}$ & $57.99 \pm 1.06$ & $109.03 \pm 1.98$ & $1.88 \pm 0.02$ \\
\hline
\end{tabular}

${ }^{1}$ Body weight gain (g/hen). ${ }^{2}$ Egg production (\%). ${ }^{3}$ Egg weight (g). ${ }^{4}$ Egg mass (g/hen/day). ${ }^{5}$ Feed intake (g/hen/day).

${ }^{6}$ Feed conversion ratio (g feed/g egg). a, b, c:Values in columns are statistically different; $\mathrm{p}<0.05$. *Results are expressed as mean \pm standard error.

The eggs were subjected to determine characteristics of eggshell quality parameters (shell breaking strength, shell weight and shell thickness) on all collected eggs produced at the last two days of each of the two week periods throughout the experiment. Eggshell breaking strength was measured using a cantilever system by applying increased pressure to the broad pole of the shell using an instrument (Egg Force Reader, Orka Food Technology, Israel). Eggs were then broken, and eggshell were separated and weighed. Eggshells were rinsed running water and dried in oven at $60^{\circ} \mathrm{C}$ for $12 \mathrm{~h}$, to determine eggshell thickness (including the membrane) in three points (one point on the air cell, and two randomised points on the equator) on the eggs using a micrometer (Mitutoyo, $0.01 \mathrm{~mm}$, Japan). Eggshells were weighed using a $0.001 \mathrm{~g}$ precision scale. Eggshell weight was calculated via: Eggshell weight $(\mathrm{g} / 100 \mathrm{~g}$ egg $)=[$ Eggshell weight (g) / Egg weight (g)]. Egg specific gravity was determined using graded salt solutions ranging from 1.060-1.100 with gradations of 0.005 (Holder and Bradford, 1979).

Eggshell and tibia $\mathrm{Ca}, \mathrm{P}$ or $\mathrm{Mg}$ contents were determined by MarsXpress Technology Inside and Inductively Coupled Plasma Atomic Emission Spectrometer (Vista AX CCD Simultaneous ICP-AES). Approximately $0.20 \mathrm{~g}$ of dried sample (eggshell without membrane, and bone with marrow removed) was put into a burning cup, and $5 \mathrm{~mL}$ nitric acid, $3 \mathrm{~mL}$ perchloric acid and $2 \mathrm{~mL}$ hydrogen peroxide was added. The sample was incinerated in a MARS 5 Microwave Oven (CEM Corp., USA, 3100 Smith Farm Road, Matthews, NC) at $190^{\circ} \mathrm{C}$ temperature and $1.207 \mathrm{kPa}$ pressure, and after diluted $50 \mathrm{~mL}$ of distilled water. Mineral concentrations were determined by an Inductively Coupled Plasma Atomic Emission Spectrometer (ICP-AES) (Skujin et al., 1998).

Data were subjected to ANOVA by using General Linear Model procedure (GLM) in Minitab (2000). Duncan's multiple range tests were applied to separate means (Mstat-C, 1995). Statements of statistical significance are based on probabilities of $\mathrm{P}<0.01$ and $\mathrm{P}<0.05$.

\section{Results and Discussion}

The egg production, egg weight, egg mass, feed intake and feed conversion ratio are shown in Table 2. Different dietary $\mathrm{Ca}$ sources had no significant effect on body weight gain, egg production, egg mass, feed intake and feed conversion ratio, but egg weight was significantly affected by the treatments $(\mathrm{P}<0.05)$. The significantly highest egg weight was found in laying hens fed with $50 \%$ fine limestone and 50\% large limestone (diet 2) whereas the lowest egg weight was observed fed with $50 \%$ fine limestone and 50\% oyster shell (diet 3 ) in laying hens.

In the present study, egg specific gravity, eggshell weight, eggshell thickness and eggshell breaking strength are presented in Table 3. Different dietary Ca sources had no significant effect on egg specific gravity, eggshell weight, eggshell thickness and eggshell breaking strength. The eggshell and tibia mineral contents are shown in Table 4. Dietary different $\mathrm{Ca}$ sources had a significant effect on $\mathrm{Ca}, \mathrm{P}$ and $\mathrm{Mg}$ as mineral contents of eggshell and tibia $(\mathrm{P}<0.01)$. The highest $\mathrm{Ca}, \mathrm{P}$ and $\mathrm{Mg}$ contents of eggshell were obtained for the groups fed with $100 \%$ fine limestone (diet 1), 50\% fine limestone and 50\% large limestone (diet 2), and $25 \%$ fine limestone, $25 \%$ large limestone, $25 \%$ oyster shell and $25 \%$ egg shell (diet 11 ), respectively. The highest $\mathrm{Ca}, \mathrm{P}$ and $\mathrm{Mg}$ contents of tibia were obtained for the group fed with $25 \%$ fine limestone, $25 \%$ large limestone, $25 \%$ oyster shell and $25 \%$ egg shell (diet 11).

The source of $\mathrm{Ca}$ did not affect the performance parameters (except for egg weight) of hens in the present study, which agrees with the report of Scheideler (1998), who did not find any effect on performance when 25 or $50 \%$ fine limestone in the diet was substituted either with oyster shell or large limestone in laying hens. Moreover, Keshavarz et al. (1993) did not observe any effect on egg production, egg mass, feed conversion ratio between $33 \%$ fine limestone and $67 \%$ oyster shell and $100 \%$ fine limestone in the diets of laying hens. Similar result was found present study for egg weight, namely egg weight 
Table 3 Effect of different calcium sources and particle size on on eggshell quality in laying hens from 44 to 56 weeks of age*

\begin{tabular}{c|cccc}
\hline Diets & $\begin{array}{c}\text { Egg specific gravity } \\
\left(\mathrm{g} / \mathrm{cm}^{3}\right)\end{array}$ & $\begin{array}{c}\text { Eggshell weight } \\
(\mathrm{g} / 100 \mathrm{~g} \mathrm{egg})\end{array}$ & $\begin{array}{c}\text { Eggshell thickness } \\
(\mathrm{mm})\end{array}$ & $\begin{array}{c}\text { Eggshell breaking } \\
\text { strength }(\mathrm{kg})\end{array}$ \\
\hline 1 & $1.0863 \pm 0.001$ & $9.65 \pm 0.15$ & $0.37 \pm 0.003$ & $3.93 \pm 0.12$ \\
2 & $1.0837 \pm 0.002$ & $9.25 \pm 0.20$ & $0.36 \pm 0.008$ & $3.89 \pm 0.15$ \\
3 & $1.0842 \pm 0.001$ & $9.40 \pm 0.11$ & $0.36 \pm 0.004$ & $4.07 \pm 0.08$ \\
4 & $1.0851 \pm 0.002$ & $9.41 \pm 0.20$ & $0.36 \pm 0.007$ & $3.88 \pm 0.10$ \\
5 & $1.0862 \pm 0.001$ & $9.62 \pm 0.09$ & $0.36 \pm 0.003$ & $3.95 \pm 0.14$ \\
6 & $1.0868 \pm 0.001$ & $9.63 \pm 0.17$ & $0.37 \pm 0.007$ & $3.94 \pm 0.17$ \\
7 & $1.0852 \pm 0.001$ & $9.44 \pm 0.11$ & $0.37 \pm 0.004$ & $3.94 \pm 0.08$ \\
8 & $1.0834 \pm 0.001$ & $9.39 \pm 0.21$ & $0.36 \pm 0.006$ & $3.77 \pm 0.15$ \\
9 & $1.0849 \pm 0.001$ & $9.49 \pm 0.17$ & $0.36 \pm 0.005$ & $3.78 \pm 0.07$ \\
10 & $1.0860 \pm 0.001$ & $9.45 \pm 0.12$ & $0.37 \pm 0.005$ & $3.80 \pm 0.04$ \\
11 & $1.0861 \pm 0.001$ & $9.49 \pm 0.15$ & $0.37 \pm 0.006$ & $4.08 \pm 0.12$ \\
\hline
\end{tabular}

*Results are expressed as mean \pm standard error.

Table 4 Effect of different calcium sources and particle size on on mineral contents of eggshell and tibia in laying hens from 44 to 56 weeks of age*

\begin{tabular}{|c|c|c|c|c|c|c|}
\hline \multirow[t]{2}{*}{ Diets } & \multicolumn{3}{|c|}{ Eggshell } & \multicolumn{3}{|c|}{ Tibia } \\
\hline & $\mathrm{Ca}(\%)$ & $\mathrm{P}(\mathrm{mg} / \mathrm{g})$ & $\mathrm{Mg}(\mathrm{mg} / \mathrm{g})$ & $\mathrm{Ca}(\%)$ & $\mathrm{P}(\%)$ & $\operatorname{Mg}(\%)$ \\
\hline 1 & $35.5 \pm 0.65^{\mathrm{A}}$ & $2.28 \pm 0.08^{\mathrm{AB}}$ & $3.77 \pm 0.10^{A}$ & $29.6 \pm 0.24^{\mathrm{B}}$ & $12.5 \pm 0.04^{\mathrm{ABC}}$ & $0.42 \pm 0.008^{\mathrm{ABC}}$ \\
\hline 2 & $34.5 \pm 0.40^{\mathrm{ABC}}$ & $2.35 \pm 0.10^{\mathrm{A}}$ & $3.75 \pm 0.95^{\mathrm{A}}$ & $29.9 \pm 0.78^{\mathrm{B}}$ & $12.7 \pm 0.278^{\mathrm{AB}}$ & $0.45 \pm 0.018^{\mathrm{AB}}$ \\
\hline 3 & $33.2 \pm 0.27^{\mathrm{BC}}$ & $2.21 \pm 0.05^{\mathrm{AB}}$ & $3.49 \pm 0.88^{\mathrm{AB}}$ & $28.7 \pm 0.59^{\mathrm{CD}}$ & $12.4 \pm 0.23^{\mathrm{ABC}}$ & $0.44 \pm 0.010^{\mathrm{AB}}$ \\
\hline 4 & $33.7 \pm 0.20^{\mathrm{BC}}$ & $2.18 \pm 0.04^{\mathrm{AB}}$ & $3.33 \pm 0.70^{\mathrm{B}}$ & $28.3 \pm 0.26^{\mathrm{DE}}$ & $12.1 \pm 0.06^{\mathrm{ABCD}}$ & $0.43 \pm 0.011^{\mathrm{ABC}}$ \\
\hline 5 & $34.5 \pm 0.32^{\mathrm{ABC}}$ & $2.26 \pm 0.03^{\mathrm{AB}}$ & $3.57 \pm 0.36^{\mathrm{AB}}$ & $29.2 \pm 0.61^{\mathrm{BC}}$ & $12.4 \pm 0.24^{\mathrm{ABC}}$ & $0.43 \pm 0.009^{\mathrm{ABC}}$ \\
\hline 6 & $34.7 \pm 0.40^{\mathrm{AB}}$ & $2.21 \pm 0.08^{\mathrm{AB}}$ & $3.54 \pm 0.65^{\mathrm{AB}}$ & $28.1 \pm 0.52^{\mathrm{DE}}$ & $12.0 \pm 0.22^{\mathrm{ABCD}}$ & $0.42 \pm 0.010^{\mathrm{ABC}}$ \\
\hline 7 & $34.1 \pm 0.57^{\mathrm{ABC}}$ & $2.10 \pm 0.05^{\mathrm{B}}$ & $3.76 \pm 0.12^{\mathrm{A}}$ & $27.0 \pm 0.64^{\mathrm{F}}$ & $11.6 \pm 0.23^{\mathrm{CD}}$ & $0.40 \pm 0.009^{\mathrm{BC}}$ \\
\hline 8 & $33.0 \pm 0.30^{\mathrm{C}}$ & $2.09 \pm 0.03^{\mathrm{B}}$ & $3.53 \pm 0.74^{\mathrm{AB}}$ & $27.6 \pm 0.50^{\mathrm{EF}}$ & $11.8 \pm 0.24^{\mathrm{BCD}}$ & $0.41 \pm 0.009^{\mathrm{BC}}$ \\
\hline 9 & $33.0 \pm 0.29^{C}$ & $2.06 \pm 0.05^{\mathrm{B}}$ & $3.58 \pm 0.80^{\mathrm{AB}}$ & $27.0 \pm 0.63^{F}$ & $11.3 \pm 0.25^{\mathrm{D}}$ & $0.42 \pm 0.007^{\mathrm{ABC}}$ \\
\hline 10 & $33.7 \pm 0.32^{\mathrm{BC}}$ & $2.10 \pm 0.05^{\mathrm{B}}$ & $3.29 \pm 0.86^{\mathrm{B}}$ & $28.5 \pm 0.50^{\mathrm{CD}}$ & $12.2 \pm 0.22^{\mathrm{ABCD}}$ & $0.39 \pm 0.006^{\mathrm{C}}$ \\
\hline 11 & $34.3 \pm 0.35^{\mathrm{ABC}}$ & $2.13 \pm 0.04^{\mathrm{AB}}$ & $3.78 \pm 0.37^{\mathrm{A}}$ & $30.6 \pm 0.77^{\mathrm{A}}$ & $13.0 \pm 0.36^{\mathrm{A}}$ & $0.46 \pm 0.021^{\mathrm{A}}$ \\
\hline
\end{tabular}

*Results are expressed as mean \pm standard error. A, B, C, D, E, F :Values in columns are statistically different; $\mathrm{p}<0.01$.

fed with the containing oyster shell of groups (diets 3,5 and 9) was lower than other groups in the present study. Different sources of Ca (100\% fine limestone, $60 \%$ fine limestone and 40\% large limestone and, $60 \%$ fine limestone and $40 \%$ oyster shell) in brown laying hens did not have any effect on body weight gain, egg production, egg weight, feed consumption and feed conversion ratio, egg shell weight and egg shell thickness (Safaa et al., 2008). In support to the present study, Pelicia et al. (2009) reported that three limestone particle size (100\% fine, $50 \%$ fine and $50 \%$ large, and $30 \%$ fine and $70 \%$ large) had no effect on egg production, egg mass, feed intake, feed conversion ratio, egg specific gravity, egg shell weight and egg shell strength in laying hens. Cheng and Coon (1990) and Guinotte and Nys (1991) concluded that larger particles limestone had no beneficial effect on egg production in laying hens. In the present study, egg weight was significantly higher in hens fed large limestone (diet 2) than in those fed with containing oyster shell (diets 3, 5 and 9). Keshavarz et al. (1993) reported that egg weight of laying hens fed the fine limestone was significantly greater than that of hens fed the $100 \%$ oyster shell for the period of 38 to 62 weeks of age. Guinotte and Nys (1991) supported this result that layer hens fed larger particles of limestone produced heavier eggs as compared to those consuming fine limestone. However, Lichovnikova (2007) reported that egg weight was significantly lower in the $29 \%$ fine limestone and $71 \%$ large limestone than other groups (32\% fine limestone and $68 \%$ oyster shell, $32 \%$ fine limestone and $68 \%$ egg shell, and $50 \%$ fine limestone and $50 \%$ large limestone). Skrivan et al. (2010) reported that, limestone particle size had no effect on shell breaking strength, and a statistically significant but limited effect on shell thickness, shell weight. Saafa et al. (2008) reported that the substitution of $40 \%$ fine limestone with coarse limestone had no significant effect on egg shell weight and egg shell thickness. Saunders-Blades et al. (2009) observed that egg specific gravity did not differ among hens fed the different $\mathrm{Ca}$ sources. The results of the present study are consistent with the findings of Pelicia et al. (2009). Cheng and Coon (1990) and Guinotte and Nys (1991) concluded that larger particles limestone had no effect on eggshell quality. There are limited studies about the effects of dietary different $\mathrm{Ca}$ sources on eggshell and tibia mineral contents. Dietary treatments in the present study had significantly effect on egg shell and tibia mineral $(C, P$ and $\mathrm{Mg}$ ) content. Our study of the results observed that 
egg shell Ca content had no influenced to the large calcium size. But, egg shell $\mathrm{P}$ and $\mathrm{Mg}$ contents and tibia $\mathrm{Ca}, \mathrm{P}$ and $\mathrm{Mg}$ contents had positively influenced to the large calcium size. In this case, particularly for the tibia mineral contents had positively influenced with diet containing more than $50 \%$ large form of calcium sources. The results of previous studied that eggshell $\mathrm{Ca}$ content was not influenced by the different dietary particle sizes of limestone (Lichovnikova, 2007; De Witt et al., 2009). Similar result was reported by the Saunders-Blades et al. (2009). Cufadar et al. (2011) reported that the lowest Ca and $\mathrm{Mg}$ contents of tibia were obtained for the group fed with the fine particle size of limestone in laying hens. Also, this study, researcher observed that a positive relationship was found between increasing particle size, and tibia $\mathrm{Ca}$ or $\mathrm{Mg}$ content.

\section{Conclusion}

In the present study, when dietary large calcium sources (limestone, oyster shell and egg shell) had no effect on performance and eggshell quality parameters in laying hens. However, dietary containing at least $50 \%$ large calcium sources had positive effect on mineral contents of tibia.

\section{Acknowledgement}

This research was financial supported by Selcuk University BAP. Project No: 10201057.

\section{References}

Ahmad HA, Balander RJ. 2003. Alternative feeding regimen of calcium source and phosphorus level for better eggshell quality in commercial layers. J. Appl. Poultry Res., 12: 509-514.

Cheng TK, Coon CN. 1990. Effect on layer performance and shell quality of switching limestone with different solubilities. Poultry Sci., 69: 2199-2203.

Cufadar Y, Olgun O, Yildiz AÖ. 2011. The effect of dietary calcium concentration and particle size on performance, eggshell quality, bone mechanical properties and tibia mineral contents in moulted laying hens, British Poultry Sci., 52: 761-768.

De Witt FH, Kuleile NP, Van Der Merwe HJ, Fair MD. 2009. Effect of limestone particle size on egg production and eggshell quality of hens during late production. S. Afr. J. Anim. Sci. 39: 37-40.

Etches RJ. 1987. Calcium logistics in the laying hen. J. Nutr., 117:619-28.

Guinotte F, Nys Y. 1991. Effects of particle size and origin of calcium sources on eggshell quality and bone mineralization in egg laying hens. Poultry Sci., 70: 583-592.

Harms RH. 1982. The influence of nutrition on eggshell quality. Part II: Phosphorus. Feedstuffs, May 17: 25-27.
Holder DP, Bradford MV. 1979. Relationship of specific gravity of chicken eggs to number of cracked eggs and percent shell. Poultry Sci., 58: 250-251.

Keshavarz IC, Scott ML, Blanchard J. 1993. The effect of solubility and particle size of calcium sources on shell quali and bone mineralization. J. Appl. Poultry Res., 93: 258-267.

Koreleski J, Swiatkiewicz S. 2004. Calcium from limestone meal and grit in laying hen diets-effect on performance, eggshell and bone quality. J. Anim. Feed Sci., 72: 1510-1514.

Lichovnikova M. 2007. The effect of dietary calcium source, concentration and particle size on calcium retention, eggshell quality and overall calcium requirement in laying hens. British Poultry Sci., 48: 71-75.

Minitab. 2000. Minitab Reference Manuel (release 13.0). Minitab Inc. State Coll., P.A., USA.

Mstat C, 1995. Mstat User's guide: statistics. Michigan State University, Michigan, USA.

NRC. 1994. National Recommendation Council, Nutrient requirement of poultry, 9th edition, National Academy Press; Washington, DC.

Pavlovski Z, Vitorovic D, Lukic M, Spasojevic I. 2003. Improving eggshell quality by replacement of pulverised limestone by granular limestone in the hen diet. Acta Vet. Hung., 53: 35-40.

Pelicia K, Garcia E, Mori C, Faitarone ABG, Silva AP, Molino AB, Vercese F, Berto DA. 2009. Calcium levels and limestone particle size in the diet of commercial layers at the end of the first production cycle. Brazilian J. Poultry Sci., 11: 87- 94.

Rao KS, Ronald DA, Adams JL, Durboraw WM. 1992. Improved limestone retention in the gizzard of commercial leghorn hens. J. Appl. Poultry Res., 1: 6-10.

Safaa HM, Serrano MP, Valencia DG, Frikha M, Jimenez-Moreno E. 2008. Productive perfonmance and egg quality of brown egglaying hens in the late phase of production as influenced by level and source calcium in the diet. Poultry Sci., 87: 20432051.

Saunders-Blades JL, Mac Isaac JL, Korver DR, Anderson DM. 2009. Effect of calcium source and particle size on production performance and bone quality of the laying hen. Poultry Sci., $88,338-353$.

Scheideler SE. 1998. Eggshell calcium effects on egg quality and ca digestibility in first- or third-cycle laying hens. J. Appl. Poultry Res., 7: 69-74.

Scheideler SE. 2004. Calcium source, particle size and calcium level for laying hen. Proceedings of the Midwest Poultry Federation Convention. St Paul MN, Midwest Poultry Federation.

Scott ML, Hull SJ, Mullenhoff PA. 1971. The calcium requirements of laying hens and effects of dietary oyster shell quality upon egg shell quality. Poultry Sci., 50: 1055-1063.

Scott ML, Nesheim MC, Young RJ. 1982. Nutrition of the Chicken. Scott \& Associates, Ithaca, New York.

Skrivan M, Marounek M, Bubancova I, Podsednicek M. 2010. Influence of limestone particle size on performance and egg quality in laying hens aged 24-36 weeks and 56-68 weeks. Anim. Feed Sci. Tech., 158: 110-114.

Skujin S. 1998. Handbook for ICP-AES (Varian-Vista) Version 1.0, A Short Guide to Vista Series (Switzerland, ICP-AES Operation, Varian Int. AG, Zug).. 